\title{
Vplyv a dosah myšlienok Vladimíra Helferta na slovenskú hudbu
}

\section{Influence and Impact of Vladimír Helfert's Ideas on the Slovak Music}

\author{
Tatiana Škapcová / tatianaskapcova@gmail.com \\ Ústav hudební vědy FF MU, Brno, CZ
}

\begin{abstract}
This study highlights the key relationships and the impact of Vladimir Helfert's ideas on Slovakia. A particular focus lies on the years of the joint Czechoslovak state when authentic music with unique Slovak features starts to formulate itself in the Slovak territory.

The key authors reflecting on Vladimír Helfert differ in their interpretation regarding the amount of interest placed on Slovakia. According to Bohumír Štědroň, it is high with a strong impact on the music criticism of that era as suggested by Hrčková or not having a major impact on Slovak musical modernism as argued by Pečman.

The study offers another point of view through the personality of Ivan Ballo who was not only influenced by Vladimír Helfert but participated in the creation of the image of the Czechoslovak relations. The correspondence between Ivan Ballo and Vladimír Helfert is of particular value as it significantly contributed to the characterization of new conditions and provides an analysis of the key work Fate and ideal (Osud a ideál) by Ján Levoslav Bella.
\end{abstract}

\section{Key words}

National music, Czechoslovak republic, relationship, influence, impact, idea 
Príspevok Bohumíra Štědroňa Helfert a Slovensko predneseného na muzikologickej konferencii, osvetl'uje vztahy Helferta ku Slovensku, pozitívnou dikciou, kde na margo tohto vztahu Štědroň píše: „Jestliže Univerzita Jana Ámose Komenského v Bratislavě udelila dr. Vladimírovi Helfertovi, profesoru hudebni vědy na bývalé Masarykově universitě v Brně, 15. zář́ 1932 pamětni medaili University Komenského v uznáni za jeho významnou činnost v oboru hudebni vědy, jež se týká i Slovenska, bylo to uznáni spravedlivé a zasloužené."1

Týmto príspevkom chcem teda poukázał na spojivá Slovenska a Helferta, ako i na možnú relevantnosť Štědroňových slov. Hlavným merítkom konštatovaní, nachádzaní východísk a v neposlednom rade konfrontácie vzţahu a dopadu myšlienok Helferta na Slovensko bude metodologický pôdorys príspevku, ktorý načrtáva: Jednak zmienky Helferta o slovenskej hudbe v jeho publikáciách v chronologickom poradí, d’alej čulú korešpondenciu vtedajších hudobných hýbatel’ov Slovenska a Helferta, a závisle od toho i vyriešenie otázky vplyvu Helfertových myšlienok na slovenskú hudbu zastrešenú v jeho metodologickej báze, o ktorej v úvode k České moderni hudbě konštatuje: „Dějiny hudby jsou mi předevšim dějinami hudebniho myšleni a hudebni tvořivosti. “2

\section{1.}

Počiatočné myšlienky začínajúce odvíjat’ klbko vzţahov sa dajú datovat’ ku 24. únoru 1918, teda niekol'ko mesiacov pred založením Prvej československej republiky, kedy Helfert píše útlu hudobnú epištolu Naše hudba a český štát. Je zaujímavé sledovat jeho pohlad na slovenskú kultúru niekol'ko mesiacov pred zrodením spoločného štátu. Prvotná zmienka o Slovensku v tomto útlom spise nenechá na seba dlho čakat', ked’ Helfert poznamenáva: "[...] pokud dá se předvídat z dně̌ního stavu hudebního života na Moravě (o slezském a slovenském zatím nelze mluvit), vyvinou se př̌́sti poměry pravděpodobně tak, že kulturním střediskem východni skupiny zemi českého státu (Moravy, Slezska a Slovenska) bude Brno."3

Prvoplánovo by sa dalo povedat, že Helfert neberie prinajmenšom na zretel' kultúrne centrum Slovenska - Bratislavu. Avšak tento počiatočný stav Helferta a jeho pohladu na Slovensko má progresívny vývoj. Postupujúc časovou osou d’alej sa totiž dostávame k zaujímavým faktom, ktoré menia spočiatku zdanlivú nesústredenost̉ na slovenské prostredie.

O desat rokov neskôr nastáva obrat v spojení Helfert a Slovensko. Vzniká totiž jeho prvá štúdia zameraná na kl’účovú osobnost̉ slovenskej hudby a síce Jána Levoslava Bellu. Helfertov pohl'ad na Bellovo dielo Osud a ideál je klúčovým pre jeho pohlad zvonku, kde nestagnuje len na rojčení o zrodení slovenskej hudby a jej d’alšieho vývoja, ale ponúka pre slovenskú hudbu klúčové poznatky pre budúci vývoj a ku dielu sa vyjadruje nielen o štruktúre, forme diela, ale Bellu vidí v súvislostiach jeho vlastného vývoja. Zaujímavým

1 NOVÁČEK, Zdenko. Česko-slovenské hudobné vzṫahy: referáty prednesené na muzikologickej konferencii v rámci BHS 1974. Bratislava: Obzor, 1979. Hudobné tradície Bratislavy a ich tvorcovia. s. 50.

2 HELFERT, Vladimír. Česká moderni hudba: studie o české hudebni tvořivosti. 1. vyd. Olomouc: Index, 1936, s. 170 .

3 HELFERT, Vladimír. Naše hudba a český stát. Praha: Melantrich, 1918, s. 32. 
faktom je, že Helfert vo svojom hodnotení vychádza z metódy, ktorá sa dá jasne dešifrovat' z vyjadrenia: „V prvni části této studie jsme poznali zdroje, z nichž vyrostla myšlenka symfonické básně Osud a ideál. Život skladatelìv byl zde tím mocným podnětem. Ale tento fakt pro konečné estetické zhodnocni díla nestačí, nebot’ mezi zdrojem inspirace a hodnotou díla může býti často velká propast. A proto nutno ještě se zastaviti u posledni otázky, jakým stylem je dílo psáno."

K tomuto faktu prispieva i korešpondencia Helferta s Ivanom Ballom, ktorý mu píše: „Retuše vpísané tužkou do partitúry z r. 1880, vypisal majster Bella z hlasov, ked' roku 1924, alebo 1925 dirigoval Osud a ideál vo Viedni, Majster sa už nepamätá, či Strauss mal v rukách partitúru, z roku 1880, ale iste vie, že dával Osud a ideál v skrátenej verzii." ${ }^{\text {" }}$

K Jánovi Levoslavovi Bellovi, ešte Helfert konštatuje: „Ke svému nadšenému a jednostrannému schumannovství byl Bella přiveden dr. Ludevitem Procházkou." Ku vzţahu Bella - Procházka, konštatuje a zároveň kriticky objasňuje v polemike: „Dovedl jej povzbuditi své potom nedokončené opery Jaroslav? Dovedl jej povzbuditi $k$ velkému dílu, které by se vyrovnávalo se současnou evropskou operou, jak činil tehdy Smetana? Nikoliv. Zase chce strhnouti skladatele v osudný okruh pisničkářrké malosti když pišse: Nejlépe by ste slovenské hudbě prospěl kdybyste komponoval nějakou dojemnou látku z prostičkého života národa slovenského, kde bystě mohl tě̌ziti z bohatých pokladu pisně národni, která musí býti nám včem východištěm, z kteréhož snažiti se musime k hudbě v pravdě národni." (dopis z 1. 4. 1877) ${ }^{6}$

\section{2.}

V pradivách súvislostí sa dostávame k osobnosti vtedajšej slovenskej publicistiky k Ivanovi Ballovi. Ten na margo Helfertovej štúdie mu píše: „ [...] nestačia mi slová, aby som Vám prejavil vd’aku za taký krásny príspevok pre Bellovo čislo Slovenských pohl'adov [...]"7 Bol to totiž práve Ivan Ballo, ktorý zorganizoval toto špeciálne číslo Slovenských pohladov. ${ }^{8}$

Že neostalo iba pri textoch, svedčia opät Ballove slová k Helfertovi mu píssuc: „Pretože záleži iste Vám - a niemenej nám - na soznámeni sa s majstrom Bellom dovolujem si Vám, slovutný pane profesor vrele odporúčat', aby ste ráčili príst’ už 1. mája, resp. 30 apríla odpoludne. Totiž s majstrom Bellom v deñ premiéry, resp. po premiere Kováča Wielanda - u nás má totiž ,premiéru' každé dva roky, aby potom úplne nezapadol - bude t’ažká reč. Bude totiž majster svrchovane vzrušený, pretože mu dielo vyvolá spomienku na vnútorné boje, z ktorých vzrástlo. "

2. mája 1929, teda o tri dni neskôr už Ballo Helfertovi konštatuje: „pišsem Vám pod úžasom mocným očistujúcim a povznášajúcim dojmom z Foerstrovej Evy a z kongeniálneho vpravde predvedenia, ktorého sa jej u nás dostalo. Bolo nám vel’mi, vel’mi l’úto, že ste neboli medzi nami

4 HELFERT, Vladimír. Osud a ideál. Slovenské pohlady, roč. 44, 1928, č. 11, s. 30.

5 Oddělení dějin hudby, Moravské zemské muzeum (ODH MZM), inv. č. 1269, sign. B 20. Dopis z 3. 11. 1928.

6 HELFERT, Vladimír. Osud a ideál, op. cit., s. 27, 28.

7 ODH MZM, inv. č. 126, sign. B 20. Dopis z 3. 11. 1928.

8 BALLO, Ivan. Ján Levoslav Bella: sbornik prác o jeho živote a diele. Turčiansky Sv. Martin: [Matica Slovenská], 1928.

9 ODH MZM, inv. č. 127, sign. A 81. Dopis z 29. 4. 1929. 
a nevideli i nesdiel’ali naše naď̌enie. Som však presvedčený, že zajtra, na Bellovom Kováčovi Wielandovi, budete vzácnym a drahým hostom naším $[\ldots]^{10}$

Logicky teda by som načrtla niekol'ko poznámok o vplyve Helferta na Ivana Ballu, pretože odtial'to sa vynie nová cesta súvislostí za hladaním dosahu myšlienok Helferta na Slovensko. Nad’a Hrčková konštatuje: „Zo štúdia Ballových kritik sa dá vybadat' celkové akceptovanie Helfertovej estetickej orientácie a hodnôt súčasnej hudby. O Helferta sa opierajú aj početné Ballove články o českej hudbe, kde sleduje a posudzuje najmä tvorbu Suka, Nováka, Ostrčila, Foerstera, ale aj - a to bolo nielen na Slovensku značné nóvum- Leoša Janáčka."

\section{3.}

Od roku 1928 a dosahu myšlienok na Ivana Ballu pod'me d’alej smerom k prítomnosti. Medzníkom je tu rok 1936 a Helfertova publikácia Česká moderni hudba. A síce: „Na Slovensku se nenašel žádný skladatel toho významu, aby mohl representovat generaci, o niž právě mluvime [...], "12 konštatuje Helfert o podmienkach v slovenskej hudbe pred prevratom. „Přićina byla v tom, že na Slovensku v době pred převratem nebylo vhodných podminek, aby tam vyrostla samostatná hudebni tradice slovenská. Bylo třeba, aby prirozené nadáni Slováků, dosvědčené ojedinělým bohatstvím lidové písně a jeji impulsivni i hlubokou emocionálností, bylo svedeno do nějakého kulturního střediska, $v$ němž by soustavnou praci několika generaci se vytvořila půda, z nǐz by mohly vyrůst nové květy hudebni kultury slovenské. "13 Helfert však nepoukazuje len na prirodzenú slovenskú naturálnu spevnost’ vo svojej analýze prečo chýba v tomto období kl’účový zjav, pokračuje: „Byl to ovšem následek politické perzekuce mad'arské, která by sotva byla připustila nějaký kolektivni útvar kulturni, v němž by se tvořilo centrálni ohnisko slovenských kulturnich snah. Jisto však je, že tento ráz slovenské kultury, tato individualistická roztřištěnost a tento nedostatek soudržního kulturniho kolektivu, z něhož by byla mohla vyrůst ukáznèná kulturni tradice slovenská, jak tomu bylo v Praze nebo i v Brně, byla hlavni př́čina, proč na Slovensku se neobjevuji skladatelé, kteři by mohli svým významem se přiradit k českým skladateliom v Praze a na Moravě."14

Ako je možné, že za štúdiou z roku 1928 o Bellovom Osude a ideále nie je zmienky o Bellovi a Helfert takto tvrdo konštatuje o stave slovenskej hudby? Avšak napokon o J.L. Bellovi predsa len poznamenáva: „Tento novoromantik měl všechny podminky, aby na Slovensku založil školu, jež by přimknutím k evropské kultuře vytvořila samostatný, individuálně vyhraněný směr slovenský. Ale opět se zde projevila ona kletba předpřevratové individualistické nesoudržnosti slovenské."15

10 ODH MZM, inv. č. 136a, sign. A 83. Dopis z 2. mája 1929.

11 HRČKOVÁ Nad’a. O význame Vladimíra Helferta pre hudobnú kritiku a tvorbu na Slovensku v medzivojnovom období. In Vladimír Helfert v českém a europském kontextu. Brno: Svaz českých skladatelů a koncertních umělců, 1987, s. 80.

12 HELFERT, Vladimír. Česká moderni hudba, op. cit., s. 274.

13 Ibid., s. 274.

14 Ibid.

15 Ibid., s. 275. 
Tentokrát ku nie príliš priaznivej atmosfére smeru Helfert k Slovensku prispieva i list Dobroslava Orla, ktorý v roku 1927 Helfertovi vyčíta: „uveřejnil jste ve svém časopise, že nebudete pěstovat polemiku. Ale Vaše správy z Bratislavy mají neustále polemickou tendenci, č́m neprospěje se ani Vašemu časopisu ani skutečným pracovniki̊m [...] nám zde nepomůže kritika, ale intensivni práce, povýšená našimi práteli v Česku a na Moravě. "16

\section{4.}

Vrátiac sa však k vyhranenému obdobiu Prvej československej republiky, kedy nastupujú zjavy Burlasom označenej generácie tridsiatych rokov a síce slovenskej hudobnej moderny, čiže Suchoňa, Moyzesa a Cikkera, je Helfert v súde pred nástupom tejto generácie interpretačne viac citlivý na situáciu na Slovensku. Kým v Čechách a na Morave je citelný progresívny postup s minulostou bohatých hudobných zjavov, o situácii po prevrate už Helfert konštatuje: „Na Slovensku rostla popřevratová skladatelská generace za zcela změněných podminek nežli dř́ve. Politická samostatnost Československa přinesla slovenské hudbě značný obrat. " 17

Avšak konfrontácie v slovenskom hudobnom živote a zmienky o Slovensku v danej publikácii nenechali na seba dlho čakat a ako Dobroslav Orel konštatuje a Helfertovi píše: „Naši komponisti jsou méně spokojeni Moyzes a Suchoň [...] Vysvétlil jsem jim, že kniha je psána jinak, než dosavadní, jak už vysvětleno v úvode [...]." ${ }^{18}$

O aké výčitky išlo? Čo sa mladým skladatelom na spôsobe zmienok Helferta o Slovensku nepáćilo? Súdiac bez korektných príkras, napätím bol pohlad predprevratovej zúfalej situácie, ako aj poznámka k Moyzesovej potrebe autokritiky, ${ }^{19}$ a výzvy $\mathrm{k}$ mladej generácii, kde poznamenáva: „Slovenská hudba rychle doháni to, co zameškala v době před převratem, takže jsme svèdky pozoruhodného vývojového procesu, kdy na nových prèdpokladech roste mladá skladatelská generace, již, doufejme, čeká úkol, aby vytvořila moderni slovenskou hudbu. "20

Ako poznamenáva Pečman vo svojej publikácii „Helfert, který se globálně slovenskou hudbou nezabýval, včlenil jeji základni problematiku do svého objevného spisu Česká moderní hudba. $V$ kontextu tohoto textu vyznèla slovenská tematika jako námètová oblast úzce souvisejici s vývojem hudby v Čechách, na Moravě a Slezsku. Mnohé Helfert naznačil, nevidèl však slovenskou hudbu v plné širí, nebot' vlastně počítal jen s hudbou v Bratislavě,, onom městě, jež po préevratu 1918 nastoupilo cestu nového, svobodného slovenského kulturního střediska."21

K doplneniu teda nielen publikácia z roku 1936 nesie zmienky o hudbe na Slovensku dvadsiateho storočia, ale práve prvá štúdia zameraná na slovenskú hudbu, a síce štúdia diela Osud a ideál Jána Levoslava Bellu, je zdrojom par excellence.

16 ODH MZM, inv. č. 295a, sign. C 131. Dopis z 22. 2. 1927.

17 HELFERT, Vladimír. Česká moderní hudba, op. cit., s. 295.

18 ODH MZM, inv. č. 2974, sign. D 743. Dopis z 4. 12. 1936.

19 Porovnaj: HELFERT, Vladimír. Česká moderní hudba, op. cit., s. 296.

20 Ibid., s. 296.

21 PEČMAN, Rudolf. Vladimír Helfert. Brno: Nadace Universitas Masarykiana, 2003, s. 111. 


\section{5.}

Je zaujímavé sledovat nadčasovost’ a promptnost Helfertových myšlienok. Kým slovenská hudba vnútorne v tomto období je plná zjavov tiahnucim ku koreňom ludovej piesne, rôznym typom sentimentálnych piesní či tanečnej hudby, je Helfertov nárok na hudbu začiatku dvadsiateho storočia nekompromisný. Myslím, že v rámci nezohladňovania sympatií, či antipatií voči jednotlivcovi, štýlu alebo forme, dokázal jeho analytický pohlad ucelene zachytit problém roztrieštenosti a hladania slovenskej hudby. Ako sa vysporiadat s prívlastkom národná, ktorým Helfert identifikuje snahy zjavov tohto obdobia? Myslím, že práve postupné vstávanie na vlastné nohy prinieslo vtedajším Slovákom pôdu pod nohami, kde sa začali identifikovat ako spoločenstvo. Roztrieštenost’ o ktorej Helfert hovorí, je podla mňa črtou na základe ktorej sa dá popísat celá vtedajšia situácia individualizovaných zjavov, ktorý hladali vlastnú sebaidentifikáciu paradoxne skrz námety kolektívne a ludové, mysliac tak približenie sa ku zachyteniu slovenského rysu. Avšak, že tvorba siahajúca po ludovom neznamená hned' vytvorenie hudby reprezentujúcej národ, je faktom toho, že práve až nástup novej generácie, v ktorej sa dosiahlo a dovŕšilo nielen spevňovanie kolektívu a ludových čŕt, ale sebaidentifikačné, psychologické a tvorčie upevnenie ludského ducha, dosiahlo to, že aj teraz už v dejinách slovenskej hudby, môžeme povedat o zakladatelskej generácii slovenskej hudby.

K záveru konštatujem, že nemôžeme ad absolutum povedat, že Helfertov primárny záujem siahal po slovenskej hudbe, na druhej strane jeho záujem, bez ružových okuliarov, aj ked' možno okrajovo, ale predsa hodnotil slovenský hudobný život vel'mi prezieravo.

$\mathrm{Z}$ vyššie spomenutej korešpondencie máme možnost̉ ex post sledovat záujem i nezáujem, ale každopádne vyvodzovanie nafúknutých záverov o tomto vztahu, nie je úlohou tohto príspevku. Ten chcel vniest̉ viac svetla najmä do interpretácie a síce, že záujem z Helfertovej strany o Slovensko bol možno nie až taký velký ako by sme si priali, o to však intenzívnejší, pravdivejší , pomáhajúcejší a ozdravujúci pre vtedajšiu slovenskú hudobnú spoločnost', vyrovnávajúcu sa s rôznymi predstavami, ktorých dopad na slovenskú hudbu nebol priaznivý. A práve tu Helfert prichádza ako záplata na ubolený slovenský údel a veci pomenúva pravdivo bez príkras. Jeho miera vplyvu je teda vplyvnou do tej miery, ako sa chceme otvorit pravde, ktorá často bolí.

Apoteózou tohto záveru snád' môže byt aj osud dvoch osôb tohto príspevku a síce Vladimíra Helferta a Ivana Ballu. Obidvaja sú totiž väznení vo fašistických celách a ich dielo zostáva ako memento. Snád' i Ballove slová k Helfertovi z listu z roku 1929, kde Ballo netušiac o spoločnom tragickom osude seba i svojho ideálu Helferta, mu úprimne píše: „Odnášajúc tento list na nádražie a spominajúc na krásnu noc, ked’ sme Vás odprevádzali a obdivovali ostrý vzduch bratislauský, budem prosit Pána Boha, aby sa nám vrúcne želanie splnilo." ${ }^{2}$

22 ODH MZM, inv. č. 136a, sign. A 83. Dopis z 2. mája 1929. 


\section{Bibliography}

BALLO, Ivan. Ján Levoslav Bella: sbornik prác o jeho živote a diele. Turčiansky Sv. Martin: [Matica Slovenská], 1928.

Helfertova česká moderni hudba: sbornik materiáli̊ muzikologické konference Katedry teorie a dĕjin hudby Hudebni fakulty AMU v Praze 29. května 1996 u př́ležitosti 60. výroči vydání kritické studie Vladimíra Helferta o české hudebni tvořivosti: program a texty nebo abstrakty referátů. Praha: Akademie múzických umění, 1996.

HELFERT, Vladimír. Naše hudba a český stát. Praha: Melantrich, 1918.

HELFERT, Vladimír. Osud a ideál. Slovenské pohlady, roč. 44, 1928, č. 11, s. 719-736.

HELFERT, Vladimír. Útok na Českou moderni hudbu. Olomouc: Index, 1937.

HELFERT, Vladimír - STEINHARD, Erich. E. Die Musik in der Tschechoslovakischen Republik. Prag: Orbis - Verlag, 1938.

HORVÁTHOVÁ, Katarína. Česká a slovenská skladatel'ská tvorba vo vzájomnej kontinuite a ovplyvnení (1918-1983): referáty prednesené na muzikologickej konferencii v rámci BHS 1984. [Bratislava: Mestský dom kultúry a osvety, 1984]. Hudobné tradície Bratislavy a ich tvorcovia.

HOŘEJŠ, Antonín. Slovenská hudba. Osudy a vývoj. In Československá vlastivěda. Díl VIII. Umění. Praha: Sfinx, 1935, s. 535-597.

HRČKOVÁ, Nad’a. Tradícia, modernost’ a slovenská hudobná kultúra 1918-1948. Bratislava: Litera, 1996, s. 254.

NOVÁČEK, Zdenko. Česko-slovenské hudobné vztahy: referáty prednesené na muzikologickej konferencii v rámci BHS 1974. Bratislava: Obzor, 1979.

PEČMAN, Rudolf. Vladimir Helfert. Brno: Nadace Universitas Masarykiana, 2003.

PEČMAN, Rudolf. Vladimír Helfert v českém a evropském kontextu: hudebněvědná konference $k$ 100. výroči narozeni pokrokového vědce a člověka, Brno 27.-28. února 1986. Brno: Svaz českých skladatelů a koncertních umělců, 1987.

ŠTĚDROŇ, Bohumír. Dr. Vladimír Helfert: (Přehled práce českého učence.). Praha: Unie českých hudebníků z povolání, 1940.

VYSLOUŽIL, Jiří a Rudolf PEČMAN. Vladimír Helfert : pokrokový vědec a člověk: studie, korespondence a vzpominky. Brno: Universita J. E. Purkyně, 1975.

ZICH, Otakar. Bellova theorie slovenské hudby. Slovenské pohl’ady 44 (1928), s. 713-719.

ZICH, Otakar. Symfonické básně Smetanozy. Hudebně estetický rozbor. Praha: Hudební matice Umělecké besedy, 1924. 
